\title{
Interaction of Methomyl with Brown Garden Snail, Eobania vermiculata (Müller), and White Snail, Theba pisana (Müller) Acetylcholinesterase Activity

\author{
Eshra, E.H ${ }^{1}$ M.S . EL- Shahaat ${ }^{2}$ and Shimaa S. Abdel-Nabi ${ }^{2}$
}

\begin{abstract}
Comparative toxicity of methomyl against two land snails Eobania vermiculata and Theba pisana was investigated. The Michaelis constant $\left(K_{m}\right)$ and maximal velocity $\left(V_{\max }\right)$ values of $E$. vermiculata and $T$. pisana $\mathrm{AChE}$ were compared. Finally, the in vivo and in vitro inhibition of $E$. vermiculata and $T$. pisana acetylcholinesterase by methomyl was studied. Results revealed that, the median lethal concentrations $\left(L C_{50}\right.$ values) of methomyl against $T$. pisana were $58.85,18.71$ and $3.87 \%$ after 24,48 and $72 \mathrm{hrs}$ posttreatment,respectively. On the other hand, $\mathrm{LC}_{50 \text { s }}$ values of methomyl against $E$. vermiculata were $2.94,0.92$ and 0.38 $\%$ after the same time, respectively. The $K_{m}$ values were 0.098 and $0.042 \mathrm{mM}$ and $V_{\max }$ values were 0.042 and 0.052 mmole/min for $E$. vermiculata and $T$. pisana AChE, respectively. Specific activity of $T$. pisana $\mathrm{AChE}$ is 1.43 times the $E$. vermiculata AChE specific activity. When $T$. pisana was exposed to methomyl at concentrations of 375 , 750 and $1875 \mathrm{ppm}$ the inhibition percentages of $\mathrm{AChE}$ were $88.74,89.44$ and $92.25 \%$, respectively. On the other hand, methomyl revealed inhibition percentages of 42.3 , 51.4 and $75.3 \%$ of $E$. vermiculata $\mathrm{AChE}$ activity at concentrations of $37.6,75.2$ and $188.0 \mathrm{ppm}$, respectively. The in vitro studies showed that, the sensitivity of $T$. pisana $\operatorname{AChE}\left(I_{50}=1.3 \mu \mathrm{M}\right)$ is 4.1 times more than the sensitivity of $E$. vermiculata $\mathrm{AChE}\left(\mathrm{I}_{50}=5.3 \mu \mathrm{M}\right)$ to methomyl.
\end{abstract}

\section{INTRODUCTION}

Snails are the most serious agricultural pests worldwide. The terrestrial snails are economic pests attacking different crops (Glen and Wilson, 1997, and Glen et al., 2000). Among the most serious land snails that attacking the agricultural crops in Egypt are the brown garden snail, Eobania vermiculata (Müller), and the white snail, Theba pisana (Müller). They are most active during the night and early morning as the environment is damp (El-Okda, 1980).

There are three common methods for controlling these pests: mechanical, biological, and chemical methods. Today chemical control is still one of the most effective methods, particularly over large areas (Moran et al., 2004; El-Shahaat et al., 2005 and Ghoneim, 2006). Among the chemical pesticides which successfully used in land snails control is methomyl.
Methomyl is a carbamate insecticide which inhibiting the acetylcholinesterase (AChE). In this study, the comparative toxicity of methomyl against two land snails $E$. vermiculata and $T$. pisana was investigated. The Michaelis constant $\left(K_{m}\right)$ and maximal velocity $\left(V_{\max }\right)$ values of $E$. vermiculata and $T$. pisana AChE were compared. Finally, the in vivo and in vitro inhibition of $E$. vermiculata and $T$. pisana acetylcholinesterase by methomyl was studied.

\section{MATERIALS AND METHODS}

Land snails: Adults of both $E$. vermeculata and $T$. pisana were collected for laboratory experiments during April, 2012 from El-Maamoura region, Alexandria. These snails were transferred to plastic cups covered with cloth netting and maintained under laboratory conditions of $27^{\circ} \mathrm{C}$ and $65 \%$ R.H. Snails were daily fed on lettuce leaves for two weeks to be acclimatized to these conditions. Dead snails were removed as soon as possible.

Insecticide: The technical grade of methomyl and its formulation; Lannate $90^{\circledR}$ SP were obtained from E.I.du Pont de Nemours \& Co.

Molluscicidal activity of methomyl against $\boldsymbol{E}$. vermiculata and $\boldsymbol{T}$. pisana: Homogenous discs of lettuce leaves were dipped in series of the formulated methomyl (Lannate $90^{\circledR} \mathrm{SP}$ ) for 5 minutes and left for dryness. The treated lettuce discs were transferred into plastic cups and 10 adult snails were placed into each cup. Each concentration had three replicates. Untreated lettuce disks were used as check treatment. Mortality percentages were recorded after 24,48 and $72 \mathrm{~h}$. posttreatments. Mortality values were corrected according to the Abbott equation (Abbott, 1925) and subjected to probit analysis (Finney, 1971). Concentrations which cause $50 \%$ mortality of treated snails $\mathrm{LC}_{50}$ values were calculated.

Biochemical studies on the AChE of E. vermiculata and $T$. pisana:

a. Tissue preparation: The mollusca shells were removed, then the soft tissues were homogenized in $0.1 \mathrm{M}$ phosphate buffer $\mathrm{pH} 8(1: 10 \mathrm{w} / \mathrm{v})$ using a glass homogenizer. The homogenates were centrifuged at

\footnotetext{
${ }^{1}$ Plant Protection Research Institute, Agricultural

Research Center, Egypt.

${ }^{2}$ Central Agricultural Pesticide LaboratoryAgricultural

Research Center, Egypt.

Email: eheshra@yahoo.com

Received Febuary 6,2014, Accepted March10, 2014
} 
$5000 \mathrm{rpm}$ for 30 minutes using a cooling centrifuge at $4{ }^{\circ} \mathrm{C}$. The supernatant was used as an $\mathrm{AChE}$ enzyme source.

b. Enzyme activity measurements: The spectrophotometric method of Ellman et al. (1961) was used, with acetylthiocholine iodide (ASChI) as a substrate. In a typical assay $150 \mu \mathrm{l}$ of the enzyme preparation were added to $3 \mathrm{ml}$ of a 1:1 mixture of 2 $\mathrm{mM}$ substrate solution and $2 \mathrm{mM}$ dithiodinitrobenzoic (DTNB). The final concentration of substrate and DTNB in the assay mixture was $1 \mathrm{mM}$. The change in absorption at 412 $\mathrm{nm}$ was monitored on Milton Roy spectronic 601. An assay mixture without enzyme was used as blank.

c. Determination of Michaelis constant $\left(K_{m}\right)$ and maximal velocity $\left(\boldsymbol{V}_{\max }\right)$ : Michaelis constant $\left(K_{m}\right)$ and maximal velocity $\left(V_{\max }\right)$ values of $E$. vermiculata and $T$. pisana AChE were determined by incubating the optimum protein amount with varying concentrations of ATChI. The Line weaverBurk plot (1/V vs. 1/[S]) was used to determine the $K_{m}$ and $V_{\max }$ values.

d. In vivo inhibition of $E$. vermiculata and $T$. pisana AChE by methomyl: E. vermiculata and $T$. pisana snails were fed on lettuce leaves dipped in the formulated methomyl (Lannate $90^{\circledR} \mathrm{SP}$ ) solutions at $1 / 10 \mathrm{LC}_{50}, 1 / 5 \mathrm{LC}_{50}$ and $1 / 2 \mathrm{LC}_{50}$. The snails in the check treatment; control were fed on untreated lettuce leaves. The samples were prepared to obtain the enzyme source as mentioned above. Enzyme activity in the different treatments was measured as mentioned above and inhibition percentages were calculated.

e. In vitro inhibition of $E$. vermiculata and $T$. pisana AChE by methomyl: The in vitro inhibition of $E$. vermiculata and $T$. pisana AChE by methomyl was determined by incubating the enzyme source with different methomyl concentrations; 0.313, 0.625, $1.25,2.5,5.0$ and $10.0 \mu \mathrm{M}$ (dissolved in $10 \mu \mathrm{l}$ acetone) for $15 \mathrm{~min}$ at $37^{\circ} \mathrm{C}$. The residual activity was measured spectrophotometrically at $412 \mathrm{~nm}$ as described before. The inhibition percentages were calculated and used to calculate the concentrations which cause $50 \%$ of the enzyme inhibition $\left(\mathrm{I}_{50}\right)$. f. Determination of protein: Protein estimation has been carried out according to the method of Lawry et al. (1951). Aliquots (600 $\mu \mathrm{l}$ each) of diluted protein solution were added to $2.5 \mathrm{ml}$ of reagent $\mathrm{C}$ (freshly prepared from reagent $\mathrm{B} \quad[0.5 \%$ $\mathrm{CuSO}_{4} .5 \mathrm{H}_{2} \mathrm{O}$ in $1 \%$ Na-K tartarate] and reagent $\mathrm{A}$ [2\% $\mathrm{Na}_{2} \mathrm{CO}_{3}$ in $\left.0.1 \mathrm{M} \mathrm{NaOH}\right]$ in a ratio of $1: 50$, respectively. The mixture was vortexed and incubated for $20 \mathrm{~min}$ at room temperature. At the end of incubation, $250 \mu 1$ of folin reagent $(1 \mathrm{~N})$ was added, vortexed vigorously and incubated for 30 min. and the developed color was measured at 750 $\mathrm{nm}$ using spectrophotometer (Milton Roy spectronic 601) against the blank. The standard curve of protein was previously established using different concentrations of bovine serum albumin (BSA) (10$100 \mu \mathrm{g} / \mu \mathrm{l})$.

Statistical analysis: Probit analysis was carried out using a PC probit program adopted by Finney (1971). Whenever appropriate, data were analyzed by using the least significant difference $\left(\mathrm{LSD}_{0.05}\right)$.

\section{RESULTS AND DISCUSSIONS}

Molluscicidal activity of methomyl against $E$. vermiculata and $T$. pisana: Terrestrial snails, $E$. vermiculata and $T$. pisana are considered as dangerous species in the Delta region, especially in northern areas of Egypt. They are also known as destructive pests, causing severe damage to vegetables, ornamentals, and citrus trees (EL-Wakil and Attia, 1999). Toxicity of methomyl against $E$. vermiculata and $T$. pisana by the dipping technique, using lettuce discs was evaluated (Tables 1 and 2). The median lethal concentrations ( $\mathrm{LC}_{50 \mathrm{~s}}$ values) of methomyl against $T$. pisana were $58.85,18.71$ and $3.87 \%$ after 24,48 and $72 \mathrm{hrs}$ posttreatment (Table 1).

On the other hand, $\mathrm{LC}_{50 \mathrm{~s}}$ values of methomyl against E. vermiculata are illustrated in Table (2). They were 2.94, 0.92 and $0.38 \%$ after 24,48 and $72 \mathrm{~h}$ posttreatment, respectively. It was obvious that the toxicity of methomyl was increased as the time of exposure increased for both $E$. vermiculata and $T$. pisana. The toxicity of methomyl against $T$. pisana was ten times less than against $E$. vermiculata after $72 \mathrm{hrs}$ of exposure.

Table 1. $\mathrm{LC}_{50}$ values of methomyl against $T$. pisana after different assay peroides

\begin{tabular}{cccccc}
\hline $\begin{array}{c}\text { Exposure } \\
\text { time (hr) }\end{array}$ & $\begin{array}{c}\mathbf{L C}_{\mathbf{5 0}} \\
\mathbf{( \% )}\end{array}$ & Lower limite & Upper limite & Slope \pm S.E & Regression equation \\
\hline 24 & 58.85 & 15.64 & 224.14 & $0.95 \pm 0.07$ & $\mathrm{y}=-4.543+0.952 \mathrm{X}$ \\
\hline 48 & 18.71 & 14.34 & 24.23 & $1.06 \pm 0.01$ & $\mathrm{y}=-3.462+1.058 \mathrm{X}$ \\
\hline 72 & 3.87 & 2.74 & 5.11 & $1.01 \pm 0.01$ & $\mathrm{y}=-2.587+1.005 \mathrm{X}$ \\
\hline
\end{tabular}


Table 2. $\mathrm{LC}_{50}$ values of methomyl against $E$. vermiculata after different assay peroides

\begin{tabular}{cccccc}
\hline $\begin{array}{c}\text { Exposure } \\
\text { time (hr) }\end{array}$ & $\begin{array}{c}\text { LC }_{\mathbf{5 0}} \\
\mathbf{( \% )}\end{array}$ & Lower limite & Upper limite & Slope \pm S.E & Regression equation \\
\hline 24 & 2.94 & 1.66 & 5.21 & $1.81 \pm 0.17$ & $\mathrm{y}=-8.072+1.806 \mathrm{x}$ \\
\hline 48 & 0.92 & 0.78 & 1.08 & $1.95 \pm 0.04$ & $\mathrm{y}=-7.745+1.954 \mathrm{x}$ \\
\hline 72 & 0.38 & 0.31 & 0.46 & $1.50 \pm 0.03$ & $\mathrm{y}=-5.371+1.503 \mathrm{x}$ \\
\hline
\end{tabular}

The potency of methomyl as an efficient oxime carbamate compound against gastropoda is coincided with Radwan et al. (1992) who indicated that the $\mathrm{LT}_{50}$ values of aldicarb, methomyl and oxamyl carbamates were 5.7, 2.31 and 3.97 days, respectively.

Biochemical studies on the AChE of E. vermiculata and T. pisana snails: The cholinesterase enzymes may be used to provide inhibition data which can be of great importance, since the enzymes from different species may differ in their substrates and inhibitor specificities. Significant evidences have been accumulated indicating that AChE possess in addition to an anionic site in the catalytic centre, peripheral anionic sites where ligands bind and exerted a regulatory role on the enzyme activity (Eldefrawi, 1985).

The ability of AChE to undergo ligand-induced conformational changes was first suggested by Changeux (1966), who observed that gallamine inhibition of Torpedo marmorata AChE was not strictly competitive in nature and these results were confirmed by Moss and Henderson (1988). This finding led to the proposal that $\mathrm{AChE}$ possesses peripheral anionic sites, distinct from the catalytic site, whereby binding of cationic ligand, could influence the catalytic properties of the enzyme.

Michaelis constant $\left(K_{m}\right)$ and maximal velocity $\left(V_{\max }\right)$ : The rate of any enzyme-catalyzed reaction depends directly on the concentration of the enzyme, as well as, it depends on the substrate concentration. With fixed enzyme concentration, an increase of substrate will result at first in a very rapid rise in velocity or reaction rate. As the substrate concentration continued to be increased, however, the increase in the rate of reaction began to slow down until, with a large substrate concentration, no further change in velocity could be achieved. The velocity of the reaction obtained at this high substrate concentration was defined as the maximum velocity of the enzyme-catalyzed reaction under the specified conditions. The substrate concentration that required to yield half the maximum velocity $(V / 2)$ is an important constant in enzyme chemistry (the concentration of substrate at which $\mathrm{V}=$ $\left.1 / 2 V_{\max }\right)$. This is value defined as Michaelis constant $\left(K_{m}\right)$. Under suitable conditions of temperature, $\mathrm{pH}$, and ionic strength of the buffer constant, this constant $\left(K_{m}\right)$ approximated the dissociation constant of an enzymesubstrate complex (Conn and Stumpf, 1966).

In the present work, $K_{m}$ and $V_{\max }$ values for $E$. vermiculata and $T$. pisana $\mathrm{AChE}$ were conducted under the suitable incubation time and protein concentrations to compare between the AChE from the two sources (Figure $1 \& 2$ ). Data obtained in this study indicated that the $K_{m}$ and $V_{\max }$ values of $E$. vermiculata and $T$. pisana AChE were different. The $K_{m}$ values were 0.098 and $0.042 \mathrm{mM}$ for $E$. vermiculata and $T$. pisana AChE, respectively. This means that the affinity between the $T$. pisana AChE and ATChI was higher than the affinity between the E. vermiculata AChE and ATChI. The $V_{\max }$ values were 0.042 and $0.052 \mathrm{mmole} / \mathrm{min}$ for the AChE of $E$. vermiculata and $T$. pisana, respectively (Figs. 1 and 2). The specific activity of $T$. pisana AChE is 1.43 times the $E$. vermiculata AChE specific activity (Table $3)$. Therefore, the enzyme from the two sources is different.

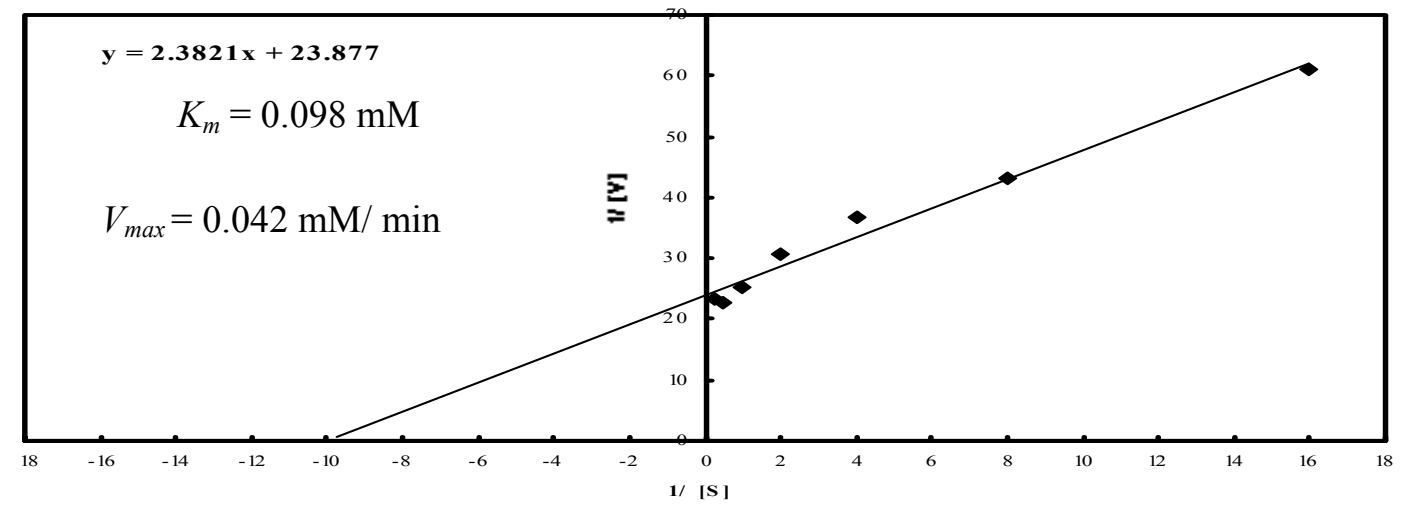


Fig. 1. Lineweavee-Burk plot for AChE from E. vermiculata

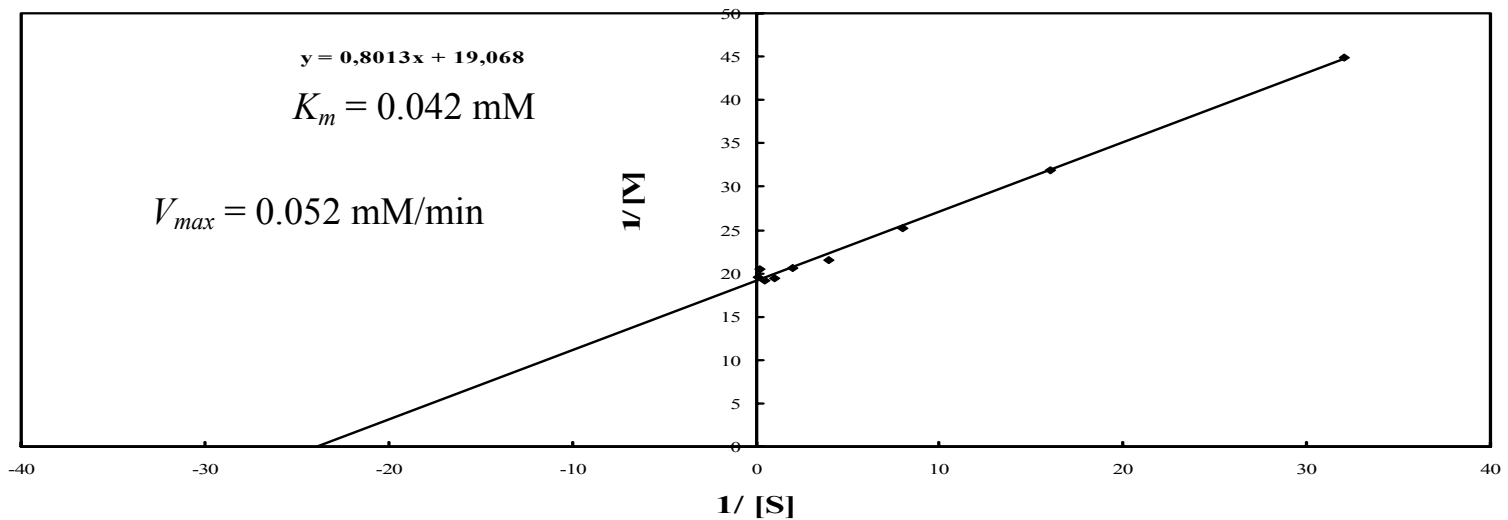

Fig. 2.Lineweaver-Burk plot from AChE from T. pisana.

Table 3. Specific activity of E. vermiculata and T. pisana AChE:

\begin{tabular}{lc}
\hline Snail & $\begin{array}{c}\text { Specific activity } \\
\left(\mathbf{\Delta} \mathbf{O D}_{\mathbf{4 1 2}} / \mathbf{m g} \text { protein } / \mathbf{m i n}\right)\end{array}$ \\
\hline E. vermiculata & $0.0099 \pm 0.00039$ \\
\hline T. pisana & $0.0142 \pm 0.00056$ \\
\hline
\end{tabular}

In vivo inhibition of $E$. vermiculata and $T$. pisana AChE activity by methomyl:

The in vivo inhibition of $E$. vermiculata and $T$. pisana AChE activity by sub-lethal concentrations of methomyl is presented in Tables (4 and 5). When $T$. pisana snails were exposed to methomyl at concentrations of 375,750 and 1875 ppm the inhibition percentages of AChE were 88.7, 89.4 and 92.3\%, respectively (Table 4). On the other hand, methomyl revealed inhibition percentages of 42.3, 51.4 and $75.3 \%$ of E. vermiculata $\mathrm{AChE}$ activity at concentrations of 37.6, 75.2 and 188.0 ppm, respectively (Table 5). From these results, it is clear that the inhibition of $E$. vermiculata and $T$. pisana AChE activity by methomyl is concentration dependent. These results are in agreement with those of Singh and Singh (2003) who stated that the inhibition of AChE activity by methomyl was both concentration and time dependent.
The inhibition of the AChE activity from land snails by methomyl had been studied by Adrian et al. (1947), who reported that the primary reason of mortality of poisoned snails by organophosphate and carbamate pesticides was due to the inhibition of AChE activity. In insects, both organophosphate and carbamate insecticides were effective as AChE inhibitors. In contrast, organophosphate and many of the carbamate compounds were ineffective when they were tested as molluscicides (Casida and Quistad, 2004). This information puts a question mark on the mode of action of methomyl as a molluscicide. In the present investigation, although methomyl inhibited $T$. pisana AChE activity (both in vivo and in vitro) more than with E. vermiculata $\mathrm{AChE}$, methomyl proved to be more toxic to $E$. vermiculata than $T$. pisana. These findings mean that land snails AChE is not the only target of methomyl.

Table 4. In vivo inhibition of AChE from T. pisana by methomyl

\begin{tabular}{cccc}
\hline Conc. $(\mathbf{p p m})$ & $\begin{array}{c}\text { Specific activity } \\
(\boldsymbol{\Delta} \text { OD412 } / \mathbf{~ m g} \text { protein } / \mathbf{m i n})\end{array}$ & Activity & Inhibition \\
\hline $\begin{array}{c}0.0142^{\mathrm{a}^{*}} \\
(0.0)\end{array}$ & 100 & 0.0 \\
\hline 375 & $\begin{array}{c}0.000558 \\
\pm 0.00016^{\mathrm{b}}\end{array}$ & 11.27 & 88.7 \\
\hline 750 & $\begin{array}{c}0.0015^{\mathrm{b}} \\
\pm 0.0000283\end{array}$ & 10.56 & 89.4 \\
\hline 1875 & $0.0011^{\mathrm{b}}$ & 7.75 & 92.3 \\
\hline
\end{tabular}


$\pm 0.000076$

L.S.D $=0.00083$

*Means followed by the same letter(s) are not significantly different.

Table 5. In vivo inhibition of AChE from $E$. vermiculata by methomyl

\begin{tabular}{lccc}
\hline Conc.(ppm) & $\begin{array}{c}\text { Speific activity } \\
\left(\Delta \mathbf{O D}_{\mathbf{4 1 2}} / \mathbf{~ m g ~ p r o t e i n . m i n ~}\right)^{2}\end{array}$ & $\begin{array}{c}\text { Activity } \\
(\%)\end{array}$ & $\begin{array}{c}\text { Inhibition } \\
(\mathbf{\%})\end{array}$ \\
\hline Control & $\begin{array}{c}0.0099^{\mathrm{a}^{*}} \\
\pm 0.00039\end{array}$ & 100 & 0.0 \\
\hline 37.6 & $\begin{array}{c}0.0057^{\mathrm{b}} \\
0.00031^{ \pm}\end{array}$ & 57.7 & 42.3 \\
\hline 75.2 & $\begin{array}{c}0.0048^{\mathrm{c}} \\
\pm 0.00004\end{array}$ & 48.6 & 51.4 \\
\hline \multirow{2}{*}{188.0} & $\begin{array}{c}0.0024^{\mathrm{d}} \\
\pm 0.00007\end{array}$ & 24.7 & 75.3 \\
\hline
\end{tabular}

L.S.D $=0.00097$

* Means followed by the same letter(s) are not significantly different.

Table 6. In vitro inhibition of AChE from $E$. vermiculata by methomyl

\begin{tabular}{|c|c|c|c|c|}
\hline Conc. $(\mu \mathrm{M})$ & $\begin{array}{c}\text { Specific activity } \\
\left(\Delta \mathrm{O} . \mathrm{D} / \mathrm{mg}_{412} \text { protein } / \mathrm{min}\right)\end{array}$ & $\begin{array}{l}\text { Activity } \\
\text { (\%control) }\end{array}$ & $\begin{array}{c}\text { Inhibition } \\
(\%)\end{array}$ & $\begin{array}{c}\mathbf{I}_{\mathbf{5 0}} \\
(\boldsymbol{\mu M})\end{array}$ \\
\hline $\begin{array}{l}\text { Control } \\
(0.0)\end{array}$ & $0.0139 \pm 0.000694$ & 100 & 0.00 & \multirow{7}{*}{5.3} \\
\hline 0.313 & $0.0138 \pm 0.000120$ & 99.94 & 0.06 & \\
\hline 0.625 & $0.0107 \pm 0.000300$ & 76.98 & 23.02 & \\
\hline 1.250 & $0.0105 \pm 0.000208$ & 75.54 & 24.55 & \\
\hline 2.500 & $0.0088 \pm 0.000208$ & 63.31 & 36.69 & \\
\hline 5.000 & $0.0072 \pm 0.000267$ & 51.80 & 48.20 & \\
\hline 10.00 & $0.0056 \pm 0.000173$ & 40.29 & 59.71 & \\
\hline
\end{tabular}

Table 7. In vitro inhibition of AChE from T. pisana by methomyl.

\begin{tabular}{|c|c|c|c|c|}
\hline Conc..$(\mu \mathrm{M})$ & $\begin{array}{c}\text { Specific activity } \\
\left(\Delta \text { O.D/mg } \text { m }_{412} \text { protein.min }\right)\end{array}$ & $\begin{array}{c}\text { Activity } \\
(\% \text { Control })\end{array}$ & $\begin{array}{c}\text { Inhibition } \\
(\%)\end{array}$ & $\begin{array}{c}\mathbf{I}_{50} \\
(\mu \mathrm{M})\end{array}$ \\
\hline $\begin{array}{l}\text { Control } \\
(0.0)\end{array}$ & $0.0186 \pm 0.000609$ & 100 & 0.00 & \multirow{7}{*}{1.3} \\
\hline 0.313 & $0.0171 \pm 0.000067$ & 91.94 & 8.06 & \\
\hline 0.625 & $0.0143 \pm 0.000145$ & 76.88 & 23.12 & \\
\hline 1.250 & $0.0094 \pm 0.000763$ & 50.70 & 49.30 & \\
\hline 2.500 & $0.0069 \pm 0.000385$ & 37.26 & 62.74 & \\
\hline 5.000 & $0.0045 \pm 0.000200$ & 24.19 & 75.81 & \\
\hline 10.00 & $0.0032 \pm 0.000329$ & 17.37 & 82.63 & \\
\hline
\end{tabular}

This may explain why methomyl has a molluscicidal activity while organophosphorous and other oximecarbamate insecticides do not have. Salama et al. (2005) stated that the mode of action of methomyl and carbofuran against land snails could be due to the induction of oxidative stress in addition to their anticholinesterase potencies.

In vitro inhibition of $E$. vermiculata and $T$. pisana AChE activity by methomyl:
The in vitro inhibition of $E$. vermiculata and $T$. pisana AChE activity by methomyl is shown in Tables (6 and 7). Methomyl at concentrations of $0.313,0.625$, $1.25, \quad 2.5, \quad 5.0$ and $10.0 \mu \mathrm{M}$ revealed inhibition percentages of $0.06,23.02,24.46,36.69,48.20$ and $59.71 \%$, respectively, on the $\mathrm{AChE}$ from $E$. vermiculata. The concentration of methomyl which inhibits $50 \%$ of the enzyme activity $\left(\mathrm{I}_{50}\right)$ is $5.3 \mu \mathrm{M}$ (Table 6). The same conc. of methomyl revealed inhibition percentages of 8.06, 23.12, 49.3, 62.74, 75.81 and $82.63 \%$, respectively, of AChE from $T$. pisana. The 
$\mathrm{I}_{50}$ value is $1.3 \mu \mathrm{M}$ (Table 7 ). The sensitivity of $T$. pisana $\mathrm{AChE}$ is 4.1 times more than the sensitivity of $E$. vermiculata AChE to methomyl.

\section{REFERENCES}

Abbott, W. S. (1925). A method of computing the effectiveness of an insecticide. J. Econ. Entomol., 18: 265267.

Adrian, E. D.; W. Feldberg and B. A. Kirby (1947). The cholinesterase action of gluorophosphonates. Brit. J. Pharmacy Cmemother., 2: 56-58.

Casida, J. E. and G.B. Quistad (2004). Why insecticides are more toxic to insects than people: The unique toxicology of insects. J. Pestic.Sci., 29 : 81-86.

Changeux, J. P. (1966). Responses of acetylcholinesterase from Torpedo marmorata to salts and curarizing drugs. Mol. Pharmacol., 2 : 369-392.

Conn, E. E. and P. K. Stumpf (1966). Enzymes, in outlines of Biochemistry (E. E. Conn and Stumpf, eds.), John Wiley and Sons, Inc. pp. 134-153.

Eldefrawi, A. T. (1985). Acetylcholinesterase and anticholinesterases. In Comprehensive Insect Physiology,Biochemistry and Pharmacology: Insect control ( G. A. Kekut and L. I. Gilbert, eds), Pergamon Press. pp. 115-130.

Ellman, G. L., K. D. Courtney, V. Andres and R. M. Featherstone (1961). A new and rapid colorimetric determination of acetylcholinesterase activity. Biochem. Pharmacol., 7 : 88-95.

El-Okda, M. M. K. (1980). Land snails of economic importance on vegetable crops at Alexandria and neighboring regions. J.Agric. Res.Rev. Egypt, 58: 79-86.

El-Shahaat, M. S., E. H. Eshra and Y. Abo-Bakr (2005). Impact of Basamide ${ }^{\circledR}$ and methomyl bait on non target pests and microbiological processes in soil. Egypt. J. Agric. Res., 83: 1007-1016.
El-Wakil, H. B. and A. M. Attia (1999). Effect of selcted insecticides on the terrestrial snails E. vermiculata (Müller) and $T$. pisana (Müller) with respect to som morphological changes in Egypt. J. Environ. Sci. Health., 34: 47-60.

Finney, D. J. (1971). Probit analysis. 3 rd edition, Cambridage Univ. Press, Cambridge, pp. 333.

Glen, D. M. and M. J. Wilson (1997). Slug-parasitic nematodes as biocontrol agents for slugs. Agro. Food. Industry Hi- Tech 8 : 23-27.

Glen, D. M. , M. J. Wilson, P. B Brain and G. Stroud (2000). Feeding activity and survival of slugs Deroceras reticulatum exposed to the rhabditid nematode Phasmarha bditis hermaphrodito: a model of dose response. Biological Control 17.73-81.

Ghoneim, E. I. (2006). Studies on controlling the terrestrial mollusca on some horticultural crops. M.S.C of Plant Protection, Fact of Agric.; Alex. Univ.(Saba Basha).

Lawery, O. H., N. J. Rosenbourgh, A. L. Farr and R. J. Rondall (1951). Protein measurement with folin phenol reagent. J. Biol. Chem., 193 : 265-275.

Moran, S., Y. Gotlib and B. Yaakov (2004). Monagement of land snails in cut green ornamentals by copper hydroxide formulations .J. Crop Protec., 23: 647-650.

Moss, D.W and A.R Henderson (1998). Enzymes. In : Tietz Fundamentos de Química Clínica, 4th ed., C.A. Burtis E.R. Ashwood (eds).Guanabara Koogan, Rio de Janeiro, p. 275-325.

Radwan, M.A., H.B. El-Wakil and K.A. Osman (1992).Toxicity and biochemical impact of certain oxime carbamate pesticides against the terrestrial snail, $T$. pisana (Müller). J.Environ. Sci. Health, 27: 759-773.

Salama, .A. K. ; K. A. Osman; N. A. Saber and S. A. Soliman (2005). Oxidative stress induced by different pesticides in the land snail, Helix aspersa. Pakistan $J$. Bio. Sci. 2005; 8: 92-96.

Singh, S. K. and A. Singh (2003). Effect of the plants Thevetia peruviana and Alstonia scholaris ( Family: Apocynaceae) on acetylcholinesterase activity of Lymnaea acuminat snails. Egypt. J. Schistos. End. Infec. Dis., 25 : 17-173. 


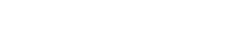 \\ تدلكل مبيد الميثومل مع نشلا النزم الستلل كولين أستربزف نوعين من الفولع الأرضيه \\ (Theba pisana g Eobania vermiculata) \\ للسيد هسن عثرة، محمدسعيد الشحكت وشيماعسعيد عبد النبى}

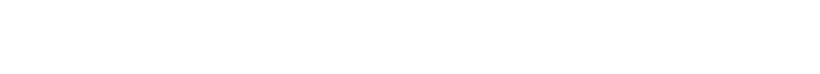
Theba pisana

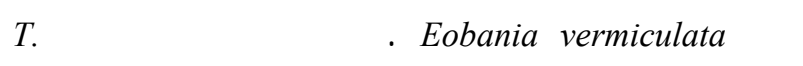
التركيزات · pisana

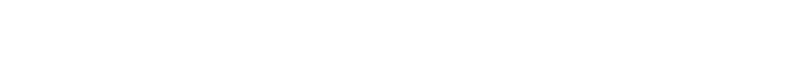

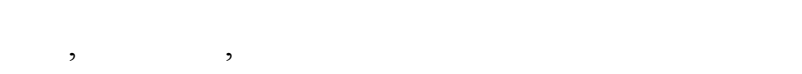

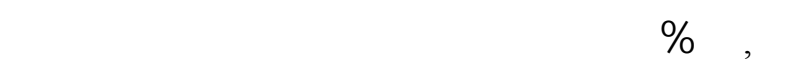

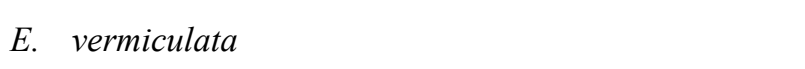

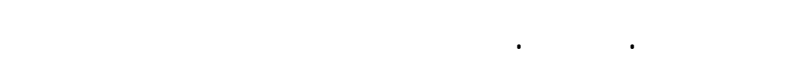

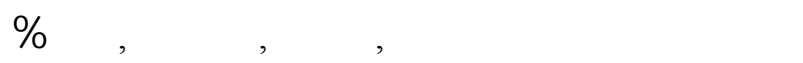
على الترتيب. جسلسية الززيم الأستيل كولين لُستريز

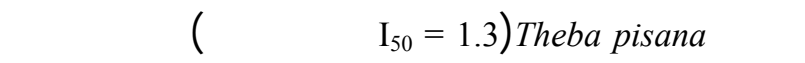
مرة قدر عسلسية عس الإنزميم القوقع لقوقع Eobania vermiculat
تمت مقارنة سمية مبيد الميثوميل على قوقعى Eobania vermiculata

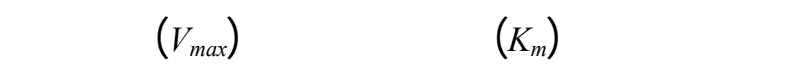
الأستيل كولين أستريز لذات القوقعين وقم دريلسة

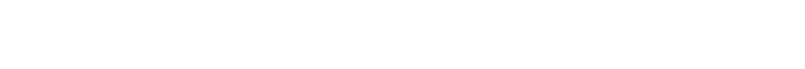
القوقعين ولقد لظٔهرت الدرلسه النتائج الآتيه: التركيز

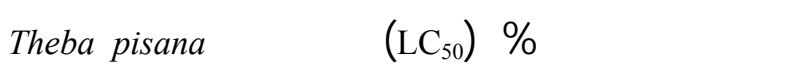
كلت

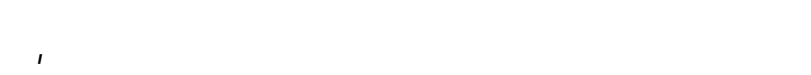

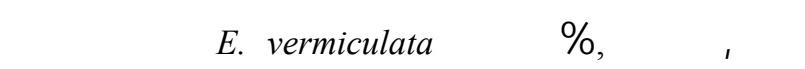

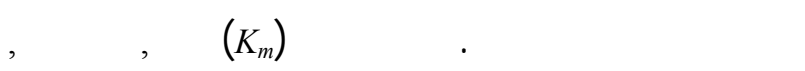
مللى مولى وقيم (

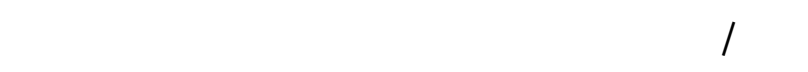
Eobania vermiculata 